\title{
The Effect of Trust on Giving: Evidence from Korean-Americans in California*
}

\author{
Seong-gin Moon**
}

\begin{abstract}
Trust in a nonprofit organization is recognized by many scholars as a pivotal function of giving activity. However, there is limited empirical evidence, and it remains unclear how trust influences giving practices. This study empirically examines the effects of trust toward nonprofit organizations on giving among Korean-Americans in California. Based on the Korean-American Philanthropic Survey, regression models are constructed to estimate such effects. The empirical results indicated a strong and positive relationship between trust in nonprofits and giving. Basically, immigrants with a greater stock of trust in nonprofits are more likely to give than their counterparts. In addition, acculturation, age, female, and religiosity are significantly and positively related to giving.
\end{abstract}

Keywords: Trust, giving, nonprofit organizations, Korean immigrants

\section{INTRODUCTION}

The last two decades have witnessed the rapid expansion of the role of nonprofit organizations in the provision of public services, including health, educational, and social services. Some have become government-by-proxy entities (Diluio, 2003; Brudney, 1990; Kim, 2005) and third-party government organizations (Solomon, 1981). However, this expanding role, widely viewed as institutional opportunities for nonprofit organizations to fulfill public missions, has imposed serious institutional challenges on the organizations. One of the major challenges is the thinning of financial resources required to meet increasing and heterogeneous public service demands. This financial challenge is related to the decline in individual generosity (giving as a

\footnotetext{
* This research is supported by Inha University.

** Seong-gin Moon is an Associate Professor at the Department of Public Administration, Inha University. E-mail: moons@inha.ac.kr.
}

Manuscript received February 9, 2017; out for review February 17, 2017; review completed March 21, 2017; accepted March 24, 2017.

The Korean Journal of Policy Studies, Vol. 32, No. 1 (2017), pp. 53-70.

(C) 2017 by the GSPA, Seoul National University 
share of personal income). The share of donations in total nonprofit revenues dropped from $37 \%$ in 1943 to $18 \%$ in 1992 (Hodgkinson, 2002). Further, the largest drop (5.4\%) in total donations (both personal and institutional) occurred in 2008 (Giving USA, 2009).

Recently, several scholars (Burnett, 1992; Herzlinger, 1996; Light, 2002; Sargeant \& Lee, 2004a; Saxton, 1995) suggested the decline of public trust in nonprofit organizations as a major contributing factor for the decline in generosity. They argued that trust is essential to the nature of the giving process in that it provides credibility and legitimacy to the nonprofit sector. People are willing to donate their money to organizations they trust and feel confident in. Organizations viewed as being wasteful and inefficient will find it difficult to obtain financial support. Although there is a general recognition that trust plays a pivotal role in facilitating donation, few empirical works have been undertaken to examine the impact of trust in nonprofits on charitable giving behaviors.

Thus, this study empirically examines the effects of trust in nonprofit organizations on giving among Korean-Americans using data from the Korean-American Philanthropic Survey. Korean-Americans are chosen for following reasons. Recently, nonprofits in the U.S. have turned their attention to ethnic minority groups as a potential funding source and have targeted them for the diversification of their revenue streams. These groups have generally been overlooked by fundraisers as mere beneficiaries of donations and have not been fully tapped in the area of philanthropic giving (Pettrey, 2002). Particularly, Korean-Americans, despite their economic and educational success, ${ }^{1}$ have showed limited participation in giving, ${ }^{2}$ although there has been some increase in the number of Korean-Americans engaged in philanthropy (Johnson, 201 1; Smith, Shue, Vest \& Villarreal, 1999).

This research is organized in the following order. First, we briefly survey the existing literature on giving decisions as well as trust in nonprofits and participation in giving. Second, we provide the methodology, describing data and variable measures and empirical results.

1. According to the U.S. Census Bureau (2007), their median household income was $\$ 52,729$ as of 2007, which is approximately $\$ 2,000$ higher than that of the non-Hispanic white population. In terms of educational achievement, $53 \%$ of Korean-Americans had a bachelor's degree or higher, whereas $49 \%$ of all Asian-Americans and $2 \%$ of non-Hispanic whites did.

2. The exact statistics about their participation is unknown. Asian Americans give 3.9 percent (of discretionary income) less to charity than White Population; they give 3.9 percent and 6.4 percent respectively (Anft and Lipman, 2003). 


\section{LITERATURE REVIEW}

\section{Giving Decisions}

Giving results from complex forms of decision making influenced by a combination of social, rational, psychological, and biological factors, among others, and is aligned with "personality, bursting with idiosyncratic visions, unsupported claims, and deeply held passions" (Frumkin, 2006, p. 253). Previous studies have identified giving based on donor motivations driven by personal values, life experiences, community norms, altruism, peer pressure, and prestige (Mount, 1996; Prince et al., 1993; Schervish, 1992).

First, giving is driven by the need to maximize utility gaining the highest returns from the decision (Amos, 1982; Krebs, 1982; Sargeant et al., 2005). This strategic giving requires collecting and processing data on the causal and transactional relationships between giving and economic and political returns. This reward-utility exchange based on individuals' actions is consistent with social exchange theory (Emerson, 1976). Specifically, giving is used as a strategic means to creating positive social images and thus promoting business reputation and customer relations (Clotfelter 1997; Frumkin, 2006; Komter, 1996; Sargeant et al., 2005). In addition, giving could be used to bring a larger tax deduction and access elite networks, a group of people with social prestige, political power, and business ties (Clotfelter, 1997; Frumkin, 2002).

Second, giving is motivated by responding to and relieving social and community expectations. This normative giving orientation is in the domain of the normative conformity model within the framework of social action, positing that actions and behaviors result from informal and normative prescriptions and proscriptions embedded in a social system (Knoke \& Wright-Isak, 1982). In this regard, giving is a type of behavior internalized as social norms and expectations in the social system where individuals are pressured to behave as directed and set by the social system to which they belong. Any behavior inconsistent with social norms is expected to be punished by embarrassment or unfavorable distinction (DiMaggio \& Powell, 1983).

Third, giving is a charitable act activated by personal moral standards and norms tailored to serving others and communities. This altruistic giving is essentially an altruistic and compassionate behavior distinct from the promotion of self-interests and needs (Monroe, 1994; Perry \& Wise, 1990). From the perspective of social learning, individuals learn and internalize this charitable act by observing and imitating role models in early childhood and through religious beliefs and education (Monroe, 1994; Moon \& Matthew, 2011). As such, education, religiosity, and parents can play import- 
ant roles in this altruistic giving.

Finally, giving is made to satisfy psychic gratification and emotional needs (Monroe, 1994; Frumkin, 2006). This psychological giving is closely related to individuals' emotional ability to understand others' deprived situations and needs. This emotional awareness is developed through imagination and sympathy (Smith, 1976). Typically, females are more likely to show empathy toward others than males, which may explain why the former are more generous (Mesch et al., 2006). Specific psychological benefits of charitable actions include stronger self-esteem and self-worth (Clary \& Snyder, 1995).

\section{Trust in Nonprofit Organizations and Giving ${ }^{3}$}

Although the definition of trust varies widely in terms of its content and scope, it can be classified at macro and micro levels (Sargeant \& Lee, 2004a). The macro perspective defines trust as "a function of collective values, social networks, and cultural ethics" for facilitating economic development (Hirschman, 1984; Perelman, 1998; Sargeant \& Lee, 2004a, p. 187; Fukuyama, 1995) and collective action (Uslaner, 1997). The micro perspective understands trust as the "willingness to increase one's vulnerability to a person whose behavior is beyond one's control" (Zand, 1972, p. 231). Rotter (1980) regarded it as "a generalized expectancy held by an individual that the word, promise, oral or written statement of another individual or group can be relied upon" (p. 1).

Trust is widely understood as a key component of social capital that fosters voluntary and coordinated actions. More specifically, trust can play a role in promoting collective activity and organizational efficiency (Alder \& Kwon, 2002), managerial problem-solving effectiveness (Zand, 1972), and philanthropic giving (Brooks, 2005; Brown \& Ferris, 2007; Sargeant \& Lee, 2004a).

Recently, the erosion of public trust in nonprofit organizations has been a growing concern for nonprofit managers and scholars. Successive problems facing nonprofit organizations, including private inurement, criminality, and organizational inefficiency, have tainted their public image as moral and civic institutions (Herzlinger, 1996). Many charity supporters are skeptical about nonprofit organizations, suggesting that these organizations are not transparent and may abuse public trust to some extent (Sargeant \& Lee, 2004a). This decline in public trust is problematic in that trust pro-

3. What we mean by giving is giving to any nonprofit organization. Here a nonprofit organization is a 501 (c) organization that is tax-exempt, including charitable, religious, educational, art, etc. 
vides the credibility and legitimacy of nonprofit organizations and grants "political license" for them to draw people's public goodwill.

Trust is essential to a high performing nonprofit organization since it can foster public' willingness to provide their financial support. Several scholars have found that the maintenance and development of trust between donors and nonprofit organizations are crucial for promoting fundraising activity (Burnett, 1992; Sargeant and Lee, 2004a, 2004b; Saxton, 1995). Basically, people do not donate to organizations they do not trust and feel confident about. This is because people expect nonprofits to be trustworthy, selflessly working for the public interest and common good. In other words, the level of trust towards nonprofits is developed only when people believe nonprofits function in a manner for fulfilling social and political obligations within society. This normative and value-oriented nature of the organizations makes them more reliant on trust. In this regard, trust towards nonprofits is likely to play a crucial role in facilitating charitable behavior from individuals in a community. This is not exceptional to immigrants in the U.S. Therefore, this study hypothesizes:

H1: Immigrants with a greater stock of trust in nonprofits are more likely to give than their counterparts.

\section{DATA AND MEASURES}

We used the Asian American Philanthropic Survey, which was conducted in California in 2009. We sent an email survey link to the 2,025 Korean-Americans who were subscribers of major Korean-American news media outlets, including newspapers, radio stations, and television networks, and asked for their participation. In addition, we posted the survey on the webpage of a newspaper and advertised it through web \& print newspaper and radio advertisements. As a result, we collected a total of 1493 responses. The following are the variable measures. Table 1 provides variable coding.

\section{Dependent Variables}

Dependent variables included participation in giving. To measure participate in giving, we asked whether they gave to charitable organizations in 2008. Those who answered "yes" were coded as one and those who answered "no" were coded as zero. Among the respondents, about $88 \%$ gave to organizations at least once a year. 
Table 1. Variable Coding

\begin{tabular}{|c|c|}
\hline Variables & Coding \\
\hline Trust in NGOs & $\begin{array}{l}\text { Measured by the level of trust in NGOs based on a five-point } \\
\text { Likert-type scale }\end{array}$ \\
\hline Level of giving & $\begin{array}{l}1=\text { less than } \$ 1,000 ; 2=\text { between } \$ 1,000 \text { and } \$ 5,000 ; 3=\text { greater } \\
\text { than } \$ 5,000 \text {. }\end{array}$ \\
\hline Acculturation & $\begin{array}{l}\text { A combined scale that is constructed using values of the individual } \\
\text { survey items }\end{array}$ \\
\hline US education & $0=$ never received US education; $1=$ received US education \\
\hline Education level & $\begin{array}{l}0=\text { not holding college diploma; } 1=\text { holding college diploma; } \\
2=\text { holding graduate diploma }\end{array}$ \\
\hline Household Income & $\begin{array}{l}1=\text { less than } \$ 50,000 ; 2=\text { between } \$ 50,000 \text { and } \$ 100,000 ; 3= \\
\text { greater than } \$ 100,000\end{array}$ \\
\hline Married & $0=$ single $; 1=$ married \\
\hline Homeowner & 1=homeowner; 0 otherwise \\
\hline Employment & $\begin{array}{l}2=\text { full-time employed; } 1=\text { part time employed; } 0= \\
\text { unemployed } 1=\text { =male; } 0=\text { =female }\end{array}$ \\
\hline Male & $1=$ male; $0=$ female \\
\hline Age & Continuous variable \\
\hline Immigration generation & $1=$ =lst generation; $2=1.5$ generation \\
\hline Legal status & $1=$ citizen; $0=$ not citizen \\
\hline Religiosity & $\begin{array}{l}\text { Frequency of attending religious services. } 1=\text { do not attend; } \\
2=\text { only major religious holidays; } 3=\text { about once a month; } 4=\text { about } \\
\text { once a week; } 5=\text { more than once a week. }\end{array}$ \\
\hline
\end{tabular}

\section{Independent Variable}

Trust in nonprofit organizations was measured by asking the respondents to indicate the extent to which they agreed with the statement: "In general, I would say that most nonprofit organizations can be trusted and that I can't be too careful about choosing nonprofit organizations for donations." Here we employed a five-point Likert-type scale ranging from "strongly disagree" (1) to "strongly agree" (5). 


\section{Control Variables}

Acculturation indicates the extent to which immigrants have successfully adapted to their host culture and society. Previous studies have suggested that immigrants with a greater level of acculturation have a stronger tendency to give than their counterparts (Chao, 2001; Putnam, 2000). This is partly because more acculturated immigrants are likely to have an opportunity to participate in labor markets and develop social contacts with others in society. This work opportunity and socializing can function as an important foundation for charitable giving.

We measured this dimension by using a combined index of multiple indicators (Cronbach's alpha $=0.72$ ) associated with the frequency of English use at home/work and with friends; preferences for American food; and socialization with Americans. We measured each indicator based on a five-point Likert-type scale ranging from "strongly disagree" (1) to "strongly agree" (5).

U.S. education attainment was measured by asking whether the respondents received a formal U.S. education. Those who answered "yes" were coded as one and "no" coded as zero. U.S. education not only offers skills and knowledge individuals need to participate in labor markets but also helps them to be adapted to U.S. culture and society (Levine, 2007). Thus, this experience increases an opportunity to participate in giving.

Education level was measured by asking the respondents to indicate the highest level of their education. We coded those respondents with no college diploma as 0 , those with a college diploma as 1 and those with a graduate diploma as 2 . Previous studies have found that education has a strong and positive relationship with participation in giving (Brown, 2001; Gittel and Tibal, 2006). Education not only provides people with access to social networks where they are asked to give but also enables them to be aware of social issues they think they can work to alleviate through giving.

Household income, although it is still debated, is considered as a factor that positively influences the decision to give (Andreoni, Gale, and Scholz, 1996; Brown, 2001) At the center of the debate is whether the effect of income is direct or indirect. Frumkin (2002) suggested that the decision to give is the indirect result of a combination of education and social pressure associated with income level rather than the direct result of income.

Household income is measure by using the respondent's gross household income before taxes. We coded the respondents such that a reported household income of $\$ 200,000$ or more was coded as 7 ; that between $\$ 150,000$ and $\$ 199,999$, as 6 ; that between $\$ 100,000$ and $\$ 149,999$, as 5 ; that between $\$ 75,000$ and $\$ 99,999$, as 4 ; that between $\$ 50,000$ and $\$ 74,999$, as 3 ; that between $\$ 25,000$ and $\$ 49,999$, as 2 ; and that 
less than $\$ 25,000$, as 1 .

Marital status was measured by asking if respondents were married. Respondents were coded as 1 if married and 0 otherwise. The literature has suggested that the married have a greater tendency to give than the single (Andreoni, Brown, and Rischall, 2003). The married are more likely to be connected and have social ties with others than the single and thereby likely to be asked for giving.

Employment was measured by asking the respondents their current employment status. We coded the respondents as 2 if they were full-time employees, 1 if they were part-time employees, and 0 if they were unemployed. Home ownership was measured by asking the respondents if they were homeowners. Homeowners were coded as 1 and non-homeowners as 0 .

Immigrant generation status was measured as follows: 1.5-generation immigrants (those born outside the U.S. who immigrated as minors) as 2 and first-generation immigrants (those who were born outside the U.S. and immigrated as adults) as 1 . Approximately $77 \%$ of the respondents were first-generation immigrants.

Citizenship was measured by asking the respondents if they were naturalized citizens. Naturalized citizens are coded 1 and 0 otherwise. We used this variable as a proxy for the level of exposure to a new culture (Negy \& Woods 1992; Ryder, Alden \& Pualhus, 2000) because it is known to be a significant predictor of participation in philanthropic activities, including volunteering (Sundeen, Garcia \& Raskoff 2009).

Gender was measured by asking the respondents if they are male or female. Males were coded as 1 and females as 0 . Approximately $67 \%$ of the respondents were male. Age was a continuous variable ranging from 21 to 67 . Previous research on charitable giving has suggested that females are more likely to donate than their male counterparts (Mesch et al. 2006; Mills 1989). Age was measured by asking the respondents to indicate their age. It ranged from 21 to 67 years old.

Finally, religiosity was an ordinal variable used to measure the frequency of attending religious services. We coded the respondents such that more than once a week was coded as 4; approximately once a week, as 3; approximately once a month as 2; only on major religious holidays, as 1 ; and no attendance, as 0 . Previous studies have suggested that people who identify themselves as being religious are more likely to donate (Hodgkinson \& Weitzman 1996). 


\section{REGRESSION RESULTS}

Binary probit regression model were constructed to estimate immigrants' participation in giving and the size of giving, respectively. Table 2 provides descriptive statis-

Table 2. Descriptive Statistics

\begin{tabular}{|c|c|c|c|}
\hline 1989 & $\begin{array}{l}\text { Simple Linear } \\
\text { Regression } \\
\text { (OLS) }\end{array}$ & Ceiling number & $\begin{array}{l}\text { Population } \\
\text { Area } \\
\text { Number of public } \\
\text { organizations } \\
\text { Revenue }\end{array}$ \\
\hline Giving & 1493 & 88 & \\
\hline Trust in NGOs & 1493 & 3.741 & 0.907 \\
\hline Acculturation & 1493 & 2.981 & 0.743 \\
\hline US education & 1493 & 48 & 0.500 \\
\hline $\begin{array}{l}\text { Education level } \\
\text { not holding college degree } \\
\text { holding college degree } \\
\text { holding graduate degree }\end{array}$ & 1493 & $\begin{array}{l}26 \\
52 \\
22\end{array}$ & \\
\hline $\begin{array}{l}\text { Household income } \\
\text { Less than } \$ 50,000 \\
\text { between } \$ 50,000 \text { and } 100,000 \\
\text { greater than } \$ 100,000\end{array}$ & 1493 & $\begin{array}{c}3.288 \\
30 \\
44 \\
26\end{array}$ & \\
\hline Married & 1493 & 83 & \\
\hline Home owner & 1493 & 46 & \\
\hline Full-time employed & 1493 & 68 & \\
\hline Male & 1493 & 67 & \\
\hline Age & 1493 & 43.184 & 9.993 \\
\hline $\begin{array}{c}\text { Generation status } \\
1.5 \text { generation } \\
\text { First generation }\end{array}$ & 1493 & $\begin{array}{c}1.177 \\
23 \\
77\end{array}$ & \\
\hline Citizen & 1493 & 43 & \\
\hline Religiosity & 1493 & 2.632 & 1.360 \\
\hline
\end{tabular}


tics table providing the mean or frequency of the variables. Table 3 provides binary probit regression estimates of Korean immigrants' giving in United States. Overall, trust in nonprofits, acculturation, household income, female, and religiosity were the strongest and positive predictors for giving.

Table 3. Regression Results for Giving

\begin{tabular}{|c|c|c|c|}
\hline \multicolumn{4}{|c|}{ Participation in giving } \\
\hline & Coef. & Std. Err. & Marginal effect \\
\hline Trust in NGOs & 0.128 & $0.038^{* * *}$ & 0.051 \\
\hline Acculturation & 0.191 & $0.050^{* * *}$ & 0.076 \\
\hline US education & -0.048 & 0.078 & -0.019 \\
\hline Education level & 0.138 & $0.051^{\star \star *}$ & 0.055 \\
\hline Household income & 0.144 & $0.029^{\star \star \star}$ & 0.057 \\
\hline Marital status & -0.230 & $0.099^{*}$ & -0.090 \\
\hline Home ownership & 0.155 & $0.077^{*}$ & 0.061 \\
\hline Employment & -0.056 & 0.051 & -0.022 \\
\hline Gender & -0.292 & $0.080^{\star \star \star}$ & -0.115 \\
\hline Age & 0.068 & $0.026^{\star *}$ & 0.027 \\
\hline Agesquare & -0.001 & $0.000^{\star}$ & 0.000 \\
\hline Immigration generation & 0.012 & 0.108 & 0.005 \\
\hline Legal status & 0.008 & 0.081 & 0.003 \\
\hline Religiosity & 0.136 & $0.026^{\star \star \star}$ & 0.054 \\
\hline Constant & -3.416 & 0.633 & \\
\hline \multicolumn{4}{|l|}{ cut 1} \\
\hline \multicolumn{4}{|l|}{ cut 2} \\
\hline \# observations & 1493.000 & & \\
\hline$\chi^{2}$ & 165.410 & & \\
\hline probability $>\chi^{2}$ & 0.000 & & \\
\hline loglikelihood & -948.325 & & \\
\hline
\end{tabular}

Note: ${ }^{*} \mathrm{p}<=.05,{ }^{* *} \mathrm{p}<=.01,{ }^{* * *} \mathrm{p}<=.005$ 
Immigrants with a greater level of trust toward nonprofits are more likely to give $(p<.001)$ than their counterparts. An additional level of trust increases the probability of giving by $5.1 \%$. This result is consistent with the hypothesis and with previous studies (Burnett, 1992; Sargeant \& Lee, 2004b).

In terms of acculturation, it is strongly and positively related to giving $(p<.001)$, meaning that those more acculturated into American society have a greater tendency to give than their counterparts. An additional level of acculturation increases the probability of giving by $7.6 \%$. This result confirms the previous finding that suggested a positive influence of acculturation on giving (Chao, 2001; Putnam, 2000).

Immigrants with a higher level of education are 5.5\% more likely to give than their counterparts $(\mathrm{p}<.006)$. Also, those with a higher level of income are 5.7\% more likely to give $(\mathrm{p}<.001)$. In addition, singles are $9 \%$ more likely to give than their counterparts $(\mathrm{p}<.002)$. This result is contradictory to the previous finding that suggested a positive relationship between female [married?] and giving. This unexpected result may be related to the fact that the first generation immigrants, mostly married and small business owners, are known to work long hours at their workplaces and thereby have almost no time to socialize with others. Basically, this immigrant lifestyle prevents the married from broadening social networks where they are asked to give.

In addition, there is a gender effect for giving; females are $11.5 \%$ more likely to give than males $(\mathrm{p}<.001)$. The older are more likely to give than their counterparts $(\mathrm{p}<.008)$. However, as a person ages (age-squared), her/his giving tends to decline (a curvilinear relationship) $(\mathrm{p}<.03)$. These results are consistent with the previous studies (Mesch et al., 2006; Mills, 1989).

Finally, immigrants with a greater level of religiosity are more likely to give than their counterparts $(\mathrm{p}<.001)$. An additional increase in religiosity increases the likelihood of giving by $5.4 \%$. This finding confirms the previous studies, suggesting that religious people are more likely to participate in giving (Hodgkinson \& Weitzman, 1996).

\section{DISCUSSION AND CONCLUSION}

This study has examined the effect of trust in nonprofit organizations on giving practices among Korean immigrants in the United States. The empirical results found that trust indeed matters in terms of promoting participation in giving. Although previous research on philanthropy has indicated that trust plays an important role in giving, few studies have provided empirical evidence.

This finding suggests that trust between donors and nonprofit organizations is an 
essential ingredient for fundraising from potential donors. The thinning of public trust towards nonprofit organizations is problematic since the credibility and legitimacy of the organizations is dependent upon public trust. Particularly, the erosion of trust in nonprofits can severely discourage voluntary involvement of ethnic minorities, including Korean Americans, who are generally underrepresented in the nonprofit sector. In turn, they continue or turn their donation efforts to informal giving practices (giving to their close social circles and ethnic community) rather than formal giving practices (giving to nonprofit charitable organizations). In order for nonprofits to maintain and promote their organizational image as moral and civic institutions, it is important to make the organizations more transparent about their financial activities and organizational management as well as make public advertisements promoting their organizational images and credibility.

In addition, other variables are also noteworthy. Education and religiosity were positively and significantly related to giving. This result is consistent with the previous findings (Brown, 1999; Clotfelter, 1997; Gittell and Tibal, 2006) that these factors are known to be important for the development and formation of moral values needed to serve others through giving. Second, acculturation (adaptation to American society and culture) was positively related to their participation in giving practices. The relationship implies that immigrants' adaption may influence their values and thus induce some changes in their behaviors. For example, as socio-cultural adaptation is advanced, personal actions based on community values imbued with Confucianism can be transferred to actions reflecting rational interests from donation (tax deduction, business reputation) and social obligation to serve others. Third, female was positively and significantly related to giving. This is related to the fact that females tend to have a greater sense of empathy towards others than males and therefore makes it easier for females to show philanthropic behavior (Brown, 2005; Mesch et al., 2006). Finally, age is an important factor that positively influences giving. This result is consistent with the previous finding that the older people tend to be more active in giving than the young (Nichols, 1992; Putnam, 2000). It is known that people aged between 50 and 64 are the most active givers (Edmonson, 1986).

This study has some limitations as follows. First, the scope of the study is limited to California, which prevents us from generalizing the empirical results to Korean-Americans' charitable behavior in the U.S. Future research should consider separating donation behavior by major states such as California, New York, New Jersey, Virginia, Texas, Washington, and Georgia and compare them in terms of their giving activities. Second, this study used cross-sectional data collected in 2009 to examine Korean-American charitable behavior. The data needs to be updated and, if possible, collected across years to represent a more accurate picture of immigrant charitable 
giving behavior.

As to future study, it should compare giving of Korean-Americans with those of other Asian immigrant groups such as Chinese-, Filipino-, Indian-, and VietnameseAmericans. Each country has certain cultural values and attitudes in common with other countries but also retains some distinct cultural heritage and historical paths. Third, future research should examine immigrants' giving under various economic environments (e.g., booms and busts) and before and after crises (e.g., earthquakes and hurricanes) to determine whether such factors can influence giving behaviors. Similarly, their motives and goals for giving may vary according to the type of crisis.

\section{REFERENCES}

Adler, Paul S. and Seok-woo Kwon. 2002. "Social Capital: Prospects for a New Concept." Academy of Management Review, 27(1): 17-40.

Amos, O. M. 1982. "Empirical analysis of motives underlying contribution to charity." Atlantic Economic Journal, 10: 45-52.

Andreoni, J., E. Brown, and I. Rischall. 2003. "Charitable Giving by Married Couples: Who Decides and Why Does It Matter?" Journal of Human Resources, 38(1): 111-133.

Anft, Michael, and Harvey Lipman. 2003. How Americans give: Chronicle study finds race is a powerful influence. Chronicle of Philanthropy.

Berry, John W. 1997. "Immigration, Acculturation, and Adaptation." Applied Psychology: An International Review, 46(1): 5-68.

. 2003. "Conceptual Approaches to Acculturation." Pp. 17-38 in Acculturation: Advances in Theory, Measurement, and Applied Research, edited by Kevin M. Chun, Pamela Balls Organista, and Gerardo Marin. Washington, DC: American Psychological Association.

Brooks, Arthur C. 2005. "Does Social Capital Make You Generous?" Social Science Quarterly, 86(1): 1-15.

Brown, E., and J. M. Ferris. 2007. "Social Capital and Philanthropy: An Analysis of the Impact of Social Capital on Individual Giving and Volunteering." Nonprofit and Voluntary Sector Quarterly, 36(1): 85-99.

Brudney, J. 1990. "Expanding the government-by-proxy construct: Volunteers in the delivery of public services." Nonprofit and Voluntary Sector Quarterly, 19(4): 315-328.

Bryant, W. K., H. Jeon-Slaughter, H. Kang, and A. Tax. 2003. "Participating in Philanthropic Activities: Donating Money and Time." Journal of Consumer Policy 
26(1): 43-73.

Burnette, A. G. 2005. "Hopscotching in the Neighborhood." New Directions for Philanthropic Fundraising, 48 (summer): 113-122.

Burt, Ronald S. 1992. Structural Holes. Cambridge, MA: Harvard University Press.

Carson, E. D. 2000. "The new rules for engaging donors of color: Giving in the twentyfirst century." New Directions for Philanthropic Fundraising, 29(Fall): 69-80.

Chao, J. 1999. "Asian-American Philanthropy: Expanding Circles of Participation." Pp. 197-253 in Cultures of Caring: Philanthropy in Diverse American Communities. Washington, DC: Special report funded by the Ford Foundation, W.K. Kellogg Foundation, David and Lucile Packard Foundation, and the Council on Foundations.

2001. Asian-American Philanthropy: Acculturation and Charitable Vehicles. Pp. 57-79 in Philanthropy in Communities of Color: Traditions and Challenges, edited by P.C. Rogers. Indianapolis: ARNOVA.

Clotfelter, C.T. (1997). "The economics of giving." In Barry, J.W. and Manno, B.V. (Eds.), Giving better, giving smarter: Working papers of the National Commission on Philanthropy and Civic Renewal (p.31-55). Washington, DC: National Commission on Philanthropy and Civic Renewal.

Decker, Paul and Eric M. Uslaner. 2001. Social Capital and Participation in Everyday Life. New York: Routledge.

Deci, E. L. 1971. Effects of externally mediated rewards on intrinsic motivation. Journal of Personality and Social Psychology, 18, 105-115. 1975. Intrinsic motivation. New York: Plenum.

Dillman, D. A. 2007. Mail and Internet Surveys: The Tailored Design Method $\left(2^{\text {nd }}\right.$ ed.). Hoboken, NJ: John Wiley \& Sons.

Diluio, J.J. "Government by proxy: A faithful overview." Harvard Law Review, 116(5): 1271-1284.

DiMaggio, P. J. and W. W. Powell.1983. "The iron cage revisited: Institutional isomorphism and collective rationality in organizational fields." American Sociological Review, 48(2): 147-160.

Emerson, R. M. 1976. "Social exchange theory." Annual Review of Sociology, 2: 335362.

Frey, B. S., and Meier S. 2005. "Selfish and Indoctrinated Economists?" European Journal of Law and Economics, 19: 165-71.

Frumkin, P. 2006. Strategic Giving: The Art and Science of Giving. Chicago: University of Chicago Press.

Fukuyama, F. 1993. "Immigrants and Family Values.” Commentary, 95(5):26-32.

Granovetter, M.S. 1973. "The Strength of Weak Ties." American Journal of Sociology, 
78(6): 1360-1380.

Greene, W. H. 2007. Econometric Analysis(5 ${ }^{\text {th }}$ ed.).Upper Saddle River, NJ: PrenticeHall Inc.

Gittell, R., and E. Tebaldi. 2006. "Charitable Giving: Factors Influencing Giving in U.S. States." Nonprofit and Voluntary Sector Quarterly, 35(4): 721-36.

Giving USA. 2009. Giving USA: The Annual Report on Philanthropy for the Year 2008. A Publication Giving USA Foundation, researched and written by the Center on Philanthropy at Indiana University.

Gordon, M. M. 1964. Assimilation in American Life. New York: Oxford University Press.

Handy, Femida and Itay Greenspan. 2009. "Immigrant Volunteering: A Stepping Stone to Integration." Nonprofit and Voluntary Sector Quarterly, 39(6): 956-982.

Herzlinger, R. E. 1996. "Can public trust in nonprofits and governments be restored?" Harvard Business Review, March-April: 97-107.

Hodgkinson, V. A. 2002. "Individual Giving and Volunteering." Pp. 387-420 in The State of Nonprofit America, edited by L. M. Salamon. Washington, DC: Brookings Institution Press.

Janoski, T., M. Musick, and J. Wilson. 1998. "Being Volunteered? The Impact of Social Participation and Pro-social Attitudes on Volunteering." Sociological Forum, 13(3): 495-519.

Johnson, Andrew S. 2011. Korean American philanthropy: Traditions, trends, and potential. San Francisco, CA: Give2Asia.

Kim, J. K.2005. "Governance, organizational effectiveness, and the nonprofit sector in Korea." Korean Journal of Policy Studies, 19(2): 15-33.

Kitano, Harry H. L., and R. Daniel. 2001. Asian-Americans: Emerging minorities (3 ${ }^{\text {rd }}$ ed.). Upper Saddle River, NJ: Prentice Hall.

Knoke, D., \& Wright-Isak, C. 1982. "Individual motives and organizational incentives systems." Research in the Sociology of Organizations, 1: 209-254.

Komter, A. E. 1996. "Reciprocity as a principal of exclusion: Gift giving in the Netherlands." Sociology, 30(2): 299-317.

Krebs, D. 1982. Altruism: A rational approach. Pp. 53-77 in The development of prosocial behavior, edited by Eisenberg N. New York: Academic Press.

Lee, Y. and S. Moon. 2011. "Mainstream and Ethnic Volunteering by Korean Immigrants in the United States." Voluntas: International Journal of Voluntary and Nonprofit Organizations, 22: 811-830.

Levi, Margaret. 1996. "Social and Unsocial Capital: A Review Essay of Robert Putnam's Making Democracy Work.” Politics \& Society, 24 (March): 45-55.

Levine, P. 2007. The future of democracy: Developing the next generation of Ameri- 
cans. Lebanon, NH: Tufts University Press.

Lewis, D. J. and A. Weigert. 1985. "Trust as a social reality." Social Forces, 63(4): 867-85.

Light, P. 2002. "Trust in charitable organizations.” Reform Watch Policy Brief. Brookings Institution.

Lin, Nan. 2001. Social Capital: A Theory of Social Structure and Action. Cambridge, UK: Cambridge University Press.

Mesch, D. J., P. M. Rooney, K. S. Steinberg, and B. Denton. 2006. "The Effects of Race, Gender, and Marital Status on Giving and Volunteering in Indiana." Nonprofit and Voluntary Sector Quarterly, 35(4): 565-87.

Min, P.G. 1992. "The Structure and Social Functions of Korean Immigrant Churches in the United States." International Migration Review, 26: 1370-1394.

. 2001. "Changes in Korean Immigrants' Gender Role and Social Status, and Their Marital Conflicts." Sociological Forum, 16(2): 301-320.

Monroe, R. M. 1994. "A fat lady in a corset: Altruism and social theory." American Journal of Political Science, 38(4): 861-893.

Moon, S. and S. Choi. 2013. "Ethnic giving versus mainstream giving by Foreignborn Korean Immigrants in California." Nonprofit and Voluntary Sector Quarterly, 42(4) 803-827.

Moon, S., and M. Downey. 2010. 'Philanthropic Motives: The 'Who' and 'Why' of Charitable Giving and Volunteering." Pp. 781-788 in Nonprofit Leadership Handbook, edited by Kathy Agard. Sage Publication.

Mount, J. 1996. "Why donors give." Nonprofit Management \& Leadership, 7(1), p. 3-14.

Newman, D. S. 2002. Opening doors: Pathways to diverse donors. San Francisco, CA: Jossey-Bass.

Osili, U. O. and D. Du. 2005. "Immigrant Assimilation and Charitable Giving." New Directions for Philanthropic Fundraising, 48: 89-104.

Perry, James L. and Wise, Lois R. 1990. "The Motivational Bases of Public Service." Public Administration Review, 50 (May/June): 367-373.

Perry, James L., Brudney, Jeffrey, Coursey, David, and Littlepage, Laura. 2008. "What Drives Morally Committed Citizens? A Study of the Antecedents of Public Service Motivation." Public Administration Review, 68(3): 445-458.

Paxton, P. 2002. "Social Capital and Democracy: An Interdependent Relationship." American Sociological Review, 6: 254-277.

Perry, James L., Brudney, Jeffrey, Coursey, David, and Littlepage, Laura. 2008. "What Drives Morally Committed Citizens? A Study of the Antecedents of Public Service Motivation." Public Administration Review, 68(3): 445-458. 
Pettrey, J. G. 2002. Cultivating Diversity in Fundraising. New York: John Wiley and Sons.

Phinney, Jean S. 2003. "Ethnic identity and acculturation.” Pp. 63-81 in Acculturation: Advances in Theory, Measurement, and Applied Research, edited by Kevin M. Chun, Pamela Balls Organista, and Gerardo Marin. Washington, DC: American Psychological Association.

Phinney, Jean S, G. Horenczyk, K. Liebkind, and P. Vedder. 2001. "Ethnic Identity, Immigration, and Well-Being: An Interactional Perspective." Journal of Social Issues, 57(3): 493-510.

Prince, R. A., K. M. File, \& J. E. Gillespie. 1993. "Philanthropic styles." Nonprofit Management \& Leadership, 3(3): 255-268.

Putnam, R. D. 1995. "Bowling Alone: America’s Declining Social Capital.” Journal of Democracy, 6(1): 65-78.

Putnam, R.D. 2000. Bowling Alone: The Collapse and Revival of American Community. New York: Simon and Schuster.

Redfield, R., R. Linton, and M. Herskovits. 1936. Memorandum on the Study of Acculturation. American Anthropologist, 38:149-52.

Rotter, J. B. 1967. "A new scale for the measurement of interpersonal trust." Journal of Personality, 39: 651-665.

Ryan, Richard M. and E. L. Deci. 2000. "Intrinsic and Extrinsic Motivations: Classic Definitions and New Directions." Contemporary Education Psychology, 25: 54-67.

Salamon, L. M. 2002. "The Resilient Sector: The State of Nonprofit American.” Pp. 3-61 in The State of Nonprofit America, edited by L. M. Salamon. Washington, DC: Brookings Institution Press.

Sanders, J., V. Nee, and S. Sernau. 2002. “Asian Immigrants' Reliance on Social Ties in a Multiethnic Labor Market." Social Forces, 81(1): 281-314.

Sargeant, A. and S. Lee. 2004a. "Donor trust and relationship commitment in the U.K. charity sector: The impact on behavior" Nonprofit and Voluntary Sector Quarterly, 33(2): 185-202.

. 2004b. "Trust and relationship commitment in the United Kingdom voluntary sector: Determinants of donor behavior." Psychology \& Marketing, 21(8): 613-635.

Sargeant, A., J. B. Ford, and D. C. West. 2005. "Perceptual determinants of nonprofit giving behavior." Journal of Business Research, 59(2): 156-165.

Saxton, J. 1995. "A strong charity brand comes from strong beliefs and values." Journal of Brand Management, 2: 211-220.

Schervish, P.G. 1992. "Adoption and altruism: Those with whom I want to share a 
dream." Nonprofit and Voluntary Sector Quarterly, 21(4): 327-350.

Shao, S. 1995. "Asian American Giving: Issues and Challenges.” New Directions for Philanthropic Giving, 8(Summer): 53-64.

Shin, K. R. 1994. "Psychosocial Prediction of Depressive Symptoms in KoreanAmerican Women in New York City." Women and Health, 21: 73-82.

Smith, B., S. Shue, J. L. Vest, and J. Villarreal. 1999. Philanthropy in Communities of Color. Bloomington, IN: Indiana University Press.

Sundeen, R. A., C. Garcia, S. A. Raskoff. 2009. "Ethnicity, Acculturation, and Volunteering to Organization: A Comparison of African Americans, Asians, Hispanics, and Whites." Nonprofit and Voluntary Sector Quarterly, 38(6): 929-55.

U.S. Census Bureau. 2006. American Community Survey. The survey was retrieved from http://www.census.gov/acs/www in March 2010.

2007. American Community Survey. The survey was retrieved from http://www.census.gov/acs/www in March 2010.

2009. American Community Survey. The survey was retrieved from http://www.census.gov/acs/www in March 2010.

Uslaner, E. 1997. The Moral Foundation of Trust. Cambridge, UK: Cambridge University Press.

Uslaner, Eric M., and Richard S. Conley. 2003. "Civic Engagement and Particularized Trust." American Politics Research, 31: 331-60.

Van Slyke, D. M., S. Ashley, and J. L. Johnson 2006. "Nonprofit Performance, Fund-raising Effectiveness, and Strategies for Engaging African Americans in Philanthropy." The American Review of Public Administration, 37(3): 278-305.

Weisinger, J. and P. Salipante. 2005. "A Grounded Theory for Building Ethnically Bridging Social Capital in Voluntary Organizations?" Nonprofit Voluntary Sector Quarterly, 34(1): 29-55.

Wong, J. S., Lien P. Conway M. M. 2005. "Group-based Resources and Political Participation among Asian Americans." American Politics Research, 33: 545-76.

Woolcock, Michael. 1998. "Social Capital and Economic Development: Toward a Theoretical Synthesis and Policy Framework." Theory and Society, 27(2): 151-208.

Zand, D. E. 1972. "Trust and managerial problem solving." Administrative Science Quarterly, 17: 229-239.

Zhou, M. 2004. "The Assimilation, the Asian Way." Pp. 139-153 in Reinventing the Melting Pot: The New Immigrants and What It Means to be American, edited by Tamar Jacoby. New York, NY: Basic Books.

Zhou, M., and S. S. Kim. 2006. "Community Forces, Social Capital, and Educational Achievement: The Case of Supplementary Education in the Chinese and Korean Immigrant Communities." Harvard Educational Review, 76(1): 1-29. 